\title{
Maternally Inherited Diabetes and Deafness (MIDD) with Undetectable C- Peptide Level and Cerebellar Atrophy
}

Yoshifumi Saisho* and Jun Inaishi

Department of Internal Medicine, Keio University School of Medicine, Tokyo, Japan

*Corresponding author: Yoshifumi Saisho, Department of Internal Medicine, Keio University School of Medicine, 35 Shinanomachi, Shinjuku-ku, Tokyo 160-8582, Japan, Tel: +81-3-3353-1211 (x62383); Fax: +81-3-3359-2745; E-mail: ysaisho@z5.keio.jp

Rec date: May 06, 2014, Acc date: May 26, 2014, Pub date: May 28, 2014

Copyright: $\odot 2014$ Saisho $\mathrm{Y}$ et al. This is an open-access article distributed under the terms of the Creative Commons Attribution License, which permits unrestricted use, distribution, and reproduction in any medium, provided the original author and source are credited.

Abstract
Maternally inherited diabetes and deafness (MIDD), also called mitochondrial diabetes mellitus, is a rare form of
diabetes that comprises $0.5-2.8 \%$ of the diabetic population. Most cases of MIDD are associated with a point
mutation in the mitochondrial DNA (mtDNA) at position 3243 of the leucine tRNA gene (A3243G). Patients with
MIDD are characterized by 1) young onset of diabetes, 2) absence of obesity, 3) neurosensory hearing loss, 4)
maternal family history of diabetes and 5) progressive insulin secretory defect. In most cases of MIDD, diabetes is
non-insulin dependent at onset, but progresses to require insulin therapy thereafter. However, to our knowledge, few
cases with MIDD show complete loss of C-peptide level during the course of the disease.

Keywords: Mitochondrial diabetes; Beta cell function; Japanese

\begin{abstract}
Abbreviations
MIDD: Maternally Inherited Diabetes and Deafness; CPR: CPeptide immunoreactivity; GAD: Glutamic Acid Decarboxylase; IA-2: Insulinoma-Associated protein-2; MRI: Magnetic Resonance Imaging; IVGTT: Intravenous Glucose Tolerance Test
\end{abstract}

\section{Case Report}

Maternally Inherited Diabetes and Deafness (MIDD), also called mitochondrial diabetes mellitus, is a rare form of diabetes that comprises $0.5-2.8 \%$ of the diabetic population [1-4]. Most cases of MIDD are associated with a point mutation in the mitochondrial DNA (mtDNA) at position 3243 of the leucine tRNA gene (A3243G) [2-4]. Patients with MIDD are characterized by 1) young onset of diabetes, 2) absence of obesity, 3) neurosensory hearing loss, 4) maternal family history of diabetes and 5) progressive insulin secretory defect [1-3,5]. In most cases of MIDD, diabetes is non-insulin-dependent at onset, but progresses to require insulin therapy thereafter. However, to our knowledge, few cases of MIDD show complete loss of C-peptide during the course of the disease.

The case was a 42 -year-old Japanese man. At the age of 34 , he attended our clinic because of thirst, polydipsia and weight loss $(5 \mathrm{~kg}$ in 6 months), and was diagnosed with diabetes (plasma glucose 436 $\mathrm{mg} / \mathrm{dl}, \mathrm{HbA} 1 \mathrm{c} 18.2 \%)$. He showed a short, lean stature (1.54 m, $41 \mathrm{~kg}$, BMI 17.3) and had had neurosensory hearing loss since childhood treated with a hearing aid. His mother also had diabetes and hearing loss, and he showed mtDNA A3243G mutation. Islet-related autoantibodies (glutamic acid decarboxylase (GAD) and insulinomaassociated protein-2 (IA-2) antibodies) were negative. $\mathrm{He}$ was diagnosed with MIDD and insulin therapy was started. Under basalbolus insulin therapy, his HbAlc level decreased to 7\%. He also had an older sister with hearing loss but not diabetes, although it was not possible to perform genetic testing in his family members.
At the time of diagnosis, serum C-peptide immnoreactivity (CPR) level was $1.1-5.3 \mathrm{ng} / \mathrm{ml}$. However, CPR level gradually declined and became undetectable $(<0.05 \mathrm{ng} / \mathrm{ml})$ from the age of 38 . Although $\mathrm{HbA1c}$ level remained at $7-8 \%$, he was admitted to our hospital at the age of 42 because of repeated episodes of hypoglycemia. At this time, he was treated with insulin lispro $5 \mathrm{U}$ before each meal and insulin glargine $7 \mathrm{U}$ at bedtime. He had neither diabetic retinopathy nor macular pattern dystrophy, but had microalbuminuria $(32.7 \mathrm{mg} / \mathrm{g}$ creatinine) and diabetic neuropathy. Serum CPR and $24 \mathrm{~h}$ urinary CPR were both undetectable $(<0.05 \mathrm{ng} / \mathrm{ml}$ and $<2 \mu \mathrm{g} /$ day, respectively). While chest X-ray and electrocardiogram were normal, brain magnetic resonance imaging (MRI) revealed cerebellar atrophy. No other abnormality such as basal ganglia calcification was detected. Continuous Subcutaneous Insulin Infusion (CSII) was introduced to prevent hypoglycemia.

Although, in general, patients with MIDD show lower insulin secretory capacity and need insulin therapy to manage hyperglycemia, usually they retain some residual CPR level [1]. Hosszufalusi et al. reported that there is a loss of first phase and total CPR response but measurable fasting CPR $(0.79-6.57 \mathrm{ng} / \mathrm{ml})$ during an intravenous glucose tolerance test (IVGTT) in patients with MIDD compared with nondiabetic controls [6]. Guillausseau et al. reported that $17 \%$ of patients with MIDD were insulin-dependent from the onset, with ketoacidosis in $8 \%$ of patients, while in the others $(83 \%)$ diabetes resembled type 2 diabetes [7], suggesting that there is heterogeneity of the diabetic phenotype in patients with MIDD, although the CPR levels of the patients were not reported. The severity of the phenotype in patients with MIDD may be associated with the degree of heteroplasmy [8] and glucose intolerance of their mothers [1].

In the present case, maternal diabetes, younger age of onset, lean stature and presence of other neurological abnormalities were consistent with the severe phenotype of MIDD. However, an undetectable CPR level is rarely seen in patients with MIDD and it is possible that his condition might have been complicated by type 1 diabetes, even though GAD and IA-2 antibodies were negative. Heterogeneity of the phenotype of MIDD may not only be associated 
Citation: Saisho Y and Inaishi J (2014) Maternally Inherited Diabetes and Deafness (MIDD) with Undetectable C-Peptide Level and Cerebellar Atrophy. J Clin Case Rep 4: 366. doi:10.4172/2165-7920.1000366

Page 2 of 2

with the degree of heteroplasmy, but also confounded by environmental or other genetic factors and possibly the coincidence of other types of diabetes.

\section{Acknowledgement}

The authors have no conflict of interest.

\section{References}

1. Suzuki S, Oka Y, Kadowaki T, Kanatsuka A, Kuzuya T, et al. (2003) Clinical features of diabetes mellitus with the mitochondrial DNA 3243 (A-G) mutation in Japanese: maternal inheritance and mitochondriarelated complications. Diabetes Res Clin Pract 59: 207-217.

2. Maassen JA, van den Ouweland JM, t Hart LM, Lemkes HH (1997) Maternally inherited diabetes and deafness: a diabetic subtype associated with a mutation in mitochondrial DNA. Horm Metab Res 29: 50-55.

3. Murphy R, Turnbull DM, Walker M, Hattersley AT (2008) Clinical features, diagnosis and management of maternally inherited diabetes and deafness (MIDD) associated with the 3243A $>\mathrm{G}$ mitochondrial point mutation. Diabet Med 25: 383-399.
4. Finsterer J (2007) Genetic, pathogenetic, and phenotypic implications of the mitochondrial A3243G tRNALeu(UUR) mutation. Acta Neurol Scand 116: 1-14.

5. Guillausseau PJ, Massin P, Dubois-LaForgue D, Timsit J, Virally M, et al. (2001) Maternally inherited diabetes and deafness: a multicenter study. Ann Intern Med 134: 721-728.

6. Hosszufalusi N, Karcagi V, Horvath R, Palik E, Varkonyi J, et al. (2009) A detailed investigation of maternally inherited diabetes and deafness (MIDD) including clinical characteristics, C-peptide secretion, HLA-DR and -DQ status and autoantibody pattern. Diabetes Metab Res Rev 25: 127-135.

7. Guillausseau PJ, Dubois-Laforgue D, Massin P, Laloi-Michelin M, Bellanné-Chantelot C, et al. (2004) Heterogeneity of diabetes phenotype in patients with 3243 bp mutation of mitochondrial DNA (Maternally Inherited Diabetes and Deafness or MIDD). Diabetes Metab 30: 181-186.

8. Laloi-Michelin M, Meas T, Ambonville C, Bellanné-Chantelot C, Beaufils S, et al. (2009) The clinical variability of maternally inherited diabetes and deafness is associated with the degree of heteroplasmy in blood leukocytes. J Clin Endocrinol Metab 94: 3025-3030. 